\title{
Acute Oral Toxicity and Anti-inflammatory and Analgesic Effects of Aqueous and Methanolic Stem Bark Extracts of Piliostigma thonningii (Schumach.)
}

\author{
Ben Olela $\mathbb{D}^{1},{ }^{1}$ James Mbaria, ${ }^{1}$ Timothy Wachira, ${ }^{1}$ and Gervason Moriasi $\mathbb{D}^{2,3}$ \\ ${ }^{1}$ Department of Public Health, Pharmacology and Toxicology, College of Veterinary and Agricultural Sciences, \\ University of Nairobi, P.O. Box 29053-00625, Nairobi, Kenya \\ ${ }^{2}$ Department of Biochemistry, Microbiology and Biotechnology, School of Pure and Applied Sciences, Kenyatta University, \\ P.O. Box 43844-00100-G.P.O, Nairobi, Kenya \\ ${ }^{3}$ Department of Medical Biochemistry, College of Health Sciences, School of Medicine, Mount Kenya University, P.O. 342-01000, \\ Thika, Kenya
}

Correspondence should be addressed to Ben Olela; benolela6@gmail.com

Received 10 March 2020; Revised 29 April 2020; Accepted 29 June 2020; Published 7 August 2020

Academic Editor: Svein Haavik

Copyright (C) 2020 Ben Olela et al. This is an open access article distributed under the Creative Commons Attribution License, which permits unrestricted use, distribution, and reproduction in any medium, provided the original work is properly cited.

Inflammation and pain are devastating conditions characterizing many diseases. Their manifestation ranges from mild body discomfort, to a debilitating experience, which may culminate in organ failure or death. In conventional medicine, corticosteroids, nonsteroidal anti-inflammatory drugs, opioids, and adjuvants are utilized to manage symptoms related to pain and inflammation. Despite their reported successes, these agents are only palliative, debatably inaccessible, unaffordable, and cause many undesirable side effects. As a result, the search for alternative and complementary therapies is warranted. Medicinal plants have been intensively utilized by humans for a long time to treat various ailments. In spite of their reported efficacies, empirical scientific data supporting their healing claims is scanty. P. thonningii (Schumach.) has been used in African traditional medicine, especially by traditional herbalists in Nigeria and Kenya, to treat conditions associated with inflammation. Even though analgesic, anti-inflammatory, and toxicity studies have been performed on leaf extracts, and some of their isolated compounds in Nigeria, there is scanty data supporting the use of stem bark extracts, which are commonly utilized in Kenya for pain, and inflammation management. Moreover, scientific data regarding safety and toxicity of the stem bark extracts of $P$. thonningii utilized in Kenya by traditional herbalists are inadequate. Based on this background, acute oral toxicity evaluation of the aqueous and methanolic stem bark extracts of $P$. thonningii, in Swiss albino mice, was performed according to the OECD/OCDE (2008) guidelines. Antiinflammatory activities were investigated using the xylene-induced ear oedema in mice, whereas analgesic activities were examined following the acetic acid-induced writhing technique. The acute oral toxicity data was analyzed, and interpreted according to the OECDE (2008) guidelines. Anti-inflammatory and analgesic activities data were tabulated on MS Excel, and exported to GraphPad Prism (v8.3). Descriptive statistics were computed, and expressed as mean \pm SEM. Thereafter, One-Way ANOVA followed by Tukey's test was performed. $p<0.05$ was considered statistically significant. All the studied plant extracts had $\mathrm{LD}_{50}$ values $>2000 \mathrm{mg} / \mathrm{kg} \mathrm{bw}$, and were hence deemed to be nontoxic according to OECD/OCDE document no. 425. The results showed that the acetic acid-induced writhing frequency in mice administered the aqueous stem bark extract of $P$. thonningii, at a dose of $500 \mathrm{mg} / \mathrm{kg} \mathrm{bw}$, was not significantly different from that recorded for mice which received the reference drug (acetylsalicylic acid $75 \mathrm{mg})(p>0.05)$. Additionally, at all the studied extract doses, significantly lower acetic acid-induced writhing frequencies were recorded in mice that received the aqueous stem bark extract of $P$. thonningii, compared with the writhing frequencies in mice that received the methanolic extract of the same plant $(p<0.05)$. On the other hand, the aqueous stem bark extract of $P$. thonningii, at doses of $100 \mathrm{mg} / \mathrm{kg}$ bw and $500 \mathrm{mg} / \mathrm{kg} \mathrm{bw}$, and the methanolic stem bark extract of the same plant, at a dose level of $500 \mathrm{mg} / \mathrm{kg} \mathrm{bw}$, exhibited significantly higher percentage inhibitions of xylene-induced oedema than the percentage inhibitions shown by the reference drug (dexamethasone $1 \mathrm{mg} / \mathrm{kg} \mathrm{bw})(p<0.05)$. Generally, the aqueous stem bark extract of $P$. thonningii, at all the studied dose levels, caused significantly higher inhibitions of xylene-induced ear oedema in mice, compared with the percentage inhibitions shown by methanolic stem bark $(p<0.05)$. Therefore, the aqueous, and methanolic stem bark extracts of $P$. thonningii, grown in Kenya, possess peripheral analgesic and anti-inflammatory activities in Swiss albino mice. Hence, they have a 
potential of offering safe analgesic, and anti-inflammatory compounds. Further studies aimed at isolating, elucidating, and characterizing bioactive components from the studied extracts are recommended. Moreover, specific mode(s) through which these extracts exert the reported bioactivities should be established. Further toxicological investigations involving the studied plant extracts are encouraged to fully establish their safety.

\section{Introduction}

Inflammation is defined as a reaction to infection, irritation, or injury to tissues. It is characterized by five cardinal features, namely, tumor (swelling/oedema), color (redness), dolor (pain), fever (warmth), and functio laesa (organ/tissue dysfunction) [1]. These responses are indispensable in successful maintenance of body's homeostasis and pathogen eradication. The underlying goal of inflammatory events is localization and elimination of harmful assaults, and removal of damaged tissues, with their components, culminating in healing of injured tissues [2].

Chronic inflammation is among the major contributors of pathologic conditions burdening both the developed and the developing nations, especially in the African continent [3]. For instance, chronic inflammation is associated with the emergency and persistence of obesity-associated diabetes mellitus after insulin resistance, among a continuum of other complex human diseases [3-5].

Many pro- and anti-inflammatory mediators are secreted during inflammatory events and during assault $[2,3,6]$. However, some of these mediators, including interleukin-12 (IL-12), exhibit both proinflammatory and anti-inflammatory features [7]. Many of these mediators have been extensively demonstrated to play integral functions in human pathologic conditions. They include eicosanoids (prostaglandins and leukotrienes), cytokines (interferons, tumor necrosis- $\alpha$, and, interleukins), chemokines (chemoattractant protein-1 and monocytes), and the nuclear factor $\mathrm{kB}$ transcription factor, which is a potent modulator of inflammation $[3,7]$.

Pain is an unpleasant sensory and emotional experience associated with potential/actual tissue damage [8]. It is a localized sensation ranging from mild discomfort to agonizing experience $[9,10]$. Stimulation of nociceptors in the skin transmits pain messages to the brain for interpretation and response. Some nociceptors only respond to severe stimulations, while others respond to innocuous and warning stimuli $[9,10]$.

Ordinarily, treatment of algesia and inflammation depends on the use of nonsteroidal anti-inflammatory drugs (NSAIDs), adjuvants, and opioids. As noted by [11], most of the drugs are either expensive or inaccessible, and they often lead to adverse effects. Conventional drugs only provide a symptomatic relief, and they are often toxic to body tissues and organs, including the liver and kidney. In this regard, plant-based medicines, such as extracts from Piliostima thonningii (Schumach), can be used for treatment $[3,12]$. This has necessitated the search for safer, affordable, and more effective alternatives to avert pain, inflammation and associated maladies. Natural products, especially those of plant origin, are more potent, easily accessible, affordable and are relatively less toxic compared to sythentic counterparts.
Piliostigma thonningii (synonym: Bauhinia thonningii) is legume of Caesalpinioideae family, growing up to 40 metres above the ground in tropical Africa [13]. Various parts of this plant are commonly used in many countries for managing various conditions including pain and inflammation [13-16].

Previous studies have demonstrated the anti-inflammatory, analgesic, and toxic effects of leaf extracts, and some compounds from leaves of $P$. thonningii in Nigeria [17-21]. However, there is no adequate scientific evidence to back the use of the stem bark extracts of $P$. thonningii in the management of pain and inflammation. To the best of our knowledge, there is no available scientific data supporting the analgesic and anti-inflammatory efficacy of the stem bark extracts of $P$. thonningii in Kenya, despite the continued ethnomedicinal applications for inflammatory disorders [16]. Additionally, the safety of the stem bark extracts of this plant, which are prominently utilized among traditional medical practitioners in Kenya, has not been determined.

Therefore, the present study aimed at investigating acute oral toxicity, anti-inflammatory, and analgesic effects of aqueous and methanolic stem bark extracts of $P$. thonningii, to provide empirical data for the discovery of well tolerable, affordable, safer, and accessible anti-inflammatory and analgesic drugs.

\section{Materials and Methods}

2.1. Plant Materials. Fresh barks of $P$. thonningii were obtained from Embu County, Kiang'ombe forest, in the natural habitat where the plant grew, with the help of a reputable local herbalist. Identification and authentication were done by a plant taxonomist at the East Africa Herbaria (National Museums of Kenya), and the plant was assigned the voucher reference number NMK/BOT/CTX/1/2. Duplicate voucher specimen was prepared and deposited at the Department of Biological Sciences, Chiromo Campus, University of Nairobi. The collected plant samples were cut into small fragments, air-dried in a well aerated room, with regular grabbling for 14 days, and ground into a coarsely powdered material using an electric mill. The powder was kept in well labelled manila bag and kept in a dry place awaiting extraction.

\subsection{Extraction Methods}

2.2.1. Methanolic Extract. Extraction was performed according to the method described by Harborne [20] and modified by [21]. Briefly, $500 \mathrm{~g}$ of the powered material was macerated in 1 liter of analytical grade methanol in a 2-liter conical flask, and then covered with a foil paper with 
constant shaking for $48 \mathrm{~h}$. The menstruum was decanted and filtered using a filter paper (Whatman No. 1). This procedure was repeated three times to exhaust extraction. The resultant filtrates were combined and reduced in vacuo at $55^{\circ} \mathrm{C}$ using a rotary evaporator. Thereafter, the extract was transferred into a clean, dry universal glass bottle, and placed in a hot-air oven set at $35^{\circ} \mathrm{C}$, for complete drying. The extract was stored at $4^{\circ} \mathrm{C}$ in a refrigerator awaiting bioassay.

2.2.2. Aqueous Extract. Approximately $100 \mathrm{~g}$ of the powdered plant materials was boiled in $750 \mathrm{ml}$ of distilled water for a period of five minutes. The mixture was filtered through a filter paper (Whatman No. 1), cooled, and then lyophilized using a freeze-dryer in vacuo. The actual weight of the dried extract was measured using an analytical balance and recorded before it was stored in a refrigerator at $4^{\circ} \mathrm{C}$ awaiting biological assay [21].

2.3. Experimental Animals. In this study, Swiss albino mice (4-5 weeks old, weighing $24 \pm 2 \mathrm{~g}$ ) were obtained from the animal breeding facility of Public Health, Pharmacology and Toxicology Department, College of Veterinary and Agricultural Science, Kabete Campus of the University of Nairobi. The experimental animals were housed in polypropylene cages measuring $30 \mathrm{~cm} \times 20 \mathrm{~cm} \times 13 \mathrm{~cm}$ in standard laboratory conditions.

The bedding comprised soft wood shavings that were evenly spread in the holding cages to provide warmth to the housed animals and to deter dumping. Standard laboratory animal pellets and tap water were provided ad libitum. Animal use and care guidelines set out by the University of Nairobi Ethical Review Committee and the National Council for Science, Technology and Innovation (NACOSTI), were followed in this study.

2.4. Preparation of Administration Doses. Following a pilot study, doses of $4 \mathrm{mg} / \mathrm{kg}$ bw, $20 \mathrm{mg} / \mathrm{kg} \mathrm{bw}, 100 \mathrm{mg} / \mathrm{kg}$ bw, and $500 \mathrm{mg} / \mathrm{kg}$ bw of the aqueous and methanolic stem bark extracts of $P$. thonningii were selected. To prepare appropriate dosages for administration to experimental mice, the OECD (2008, Document No. 425) guidelines illustrated by [22] were adopted. Briefly, to prepare a stock solution, of dose level $500 \mathrm{mg} / \mathrm{kg}$ bw, to be administered to a mouse weighing $20 \mathrm{~g}$, the formula posited by [22] was followed as demonstrated:

$$
\begin{aligned}
\operatorname{animal} \operatorname{dose}(\mathrm{mg} / \mathrm{kg} \mathrm{bw})= & \frac{\text { body weight of the animal }(\mathrm{g})}{1000 \mathrm{~g}} \\
& \times \text { selected dose [15], }
\end{aligned}
$$

so animal dose $(\mathrm{mg} / \mathrm{kg} \mathrm{bw})=20(\mathrm{~g}) / 1000 \mathrm{~g} \times 500 \mathrm{mg}$ $=10 \mathrm{mg}$.

According to the OECD [23] guidelines, $10 \mathrm{mg}$ should be reconstituted in $0.2 \mathrm{ml}$ of the vehicle (normal saline). In this study, a $10 \mathrm{ml}$ stock solution containing $500 \mathrm{mg} / \mathrm{kg} \mathrm{bw}$ of either the aqueous or the methanolic stem bark extracts of $P$. thonningii was prepared and serially diluted with normal saline to obtain $100 \mathrm{mg} / \mathrm{kg} \mathrm{bw}, 20 \mathrm{mg} / \mathrm{kg}$ bw, and $4 \mathrm{mg} / \mathrm{kg}$ bw doses. The same procedure was followed for the standard drug (dexamethasone, $10 \mathrm{mg}$ ).

2.5. Acute Oral Toxicity Effects of the Aqueous and Methanolic Stem Bark Extracts of P. thonningii. To evaluate and appraise safety of the studied plant extracts, the Up-and-Down Procedure (UDP) for acute oral toxicity described by OECD [23] was adopted. The experimental mice were randomly selected and labelled with a permanent marker pen on their tails.

The mice were housed individually in polypropylene cages for 48 hours to help them acclimatize before being subjected to the study. Afterwards, an initial dose of $175 \mathrm{mg} /$ $\mathrm{kg}$ bw was orally administered to the experimental group consisting of three (3) mice and $10 \mathrm{ml} / \mathrm{kg} \mathrm{bw}$ of normal saline to the control group ( 3 mice).

Afterwards, wellness parameters including appearance of mucous membrane, eyes, skin fur, salivation, convulsions, lethargy, coma, sleep, diarrhea, tremors, body weight deviation, and mortality were monitored and recorded after 30 minutes, 1 hour, 4 hours, 24 hours, 48 hours, 7 days, and 14 days respectively [23]. The same procedure was adopted for a $550 \mathrm{mg} / \mathrm{kg}$ bw dose and for the cut-off dose of $2000 \mathrm{mg} /$ kg bw [23].

2.6. In Vivo Anti-Inflammatory Effects of the Aqueous and Methanolic Stem Bark Extracts of P. thonningii. In this study, the xylene-induced ear oedema technique described by Igbe et al. [21] was adopted. Experimental mice were randomly divided into six groups (A, B, C, D, E, and F), with each group having five (5) mice. Mice in groups A, B, C, and D, respectively, were orally administered with $4 \mathrm{mg} / \mathrm{kg}$ bw, $20 \mathrm{mg} /$ $\mathrm{kg} \mathrm{bw}, 100 \mathrm{mg} / \mathrm{kg} \mathrm{bw}$, and $500 \mathrm{mg} / \mathrm{kg}$ bw of the studied plant extracts p.o. and 1 drop of xylene topically. The control groups (E and F, respectively) received $1 \mathrm{mg} / \mathrm{kg}$ bw of dexamethasone as positive control and $10 \mathrm{ml} / \mathrm{kg}$ bw of distilled water as negative control respectively, p.o. and 1 drop of xylene topically. The volume of administration was $200 \mu \mathrm{l}$ for all the agents except for xylene which was administered by smearing 1 drop of xylene on the inner pinna of the right ear.

After 60 minutes, oedema in each mouse was induced by smearing 1 drop of xylene on the inner pinna of the right and left ears for 15 minutes. Afterwards, the experimental mice were anesthetized using diethyl ether and both the right (oedematous) and left ears were dissected and accurately weighed using an analytical balance. The respective weights were recorded and used to calculate the anti-inflammatory effects of the extracts and expressed as the percentage inhibition of oedema according to the formula described by Igbe et al. [21]:

$$
\% \text { inhibition of edema }=\frac{A-B}{A} \times 100,
$$

where $A$ is the difference in ear weight in the negative control and $B$ is the difference in ear weight in the experimental/ positive control mice. 
2.7. Determination of the Analgesic (Antinociceptive) Activity of the Aqueous and Methanolic Stem Bark Extracts of P. thonningii. Peripheral analgesic effects of the aqueous and methanolic stem bark extracts of $P$. thonningii were evaluated using the acetic acid-induced writhing method of [24] in Swiss albino mice. A completely randomized study design was adopted, from which the experimental design was drawn. In this design, experimental mice were randomly assigned to six groups (I, II, III, IV, V, and VI), with each consisting of 5 animals. Groups I, II, III, and IV received an oral treatment of $4 \mathrm{mg} / \mathrm{kg} \mathrm{bw}, 20 \mathrm{mg} / \mathrm{kg} \mathrm{bw}, 100 \mathrm{mg} / \mathrm{kg} \mathrm{bw}$, and $500 \mathrm{mg} / \mathrm{kg} \mathrm{bw}$, respectively, of the studied plant extracts p.o. On the other hand, groups V and VI received $75 \mathrm{mg} /$ $\mathrm{kg}$ bw of acetylsalicylic acid (Aspirin) and $10 \mathrm{ml} / \mathrm{kg} \mathrm{bw}$ of distilled water orally as positive and negative controls, respectively. After 30 minutes, writhing was induced in each experimental mouse with an intraperitoneal injection of $0.6 \% \mathrm{v} / \mathrm{v}$ acetic acid. All the drugs were administered at a volume of $200 \mu \mathrm{l}$.

Thereafter, experimental mice were monitored individually, and the number of writhes was counted after 5 minutes of writhing induction, for 30 minutes, and recorded. The average number of writhes and the percentage inhibition of writhing were calculated as an indicator of analgesic activity following the equation described by Rashid et al. [24]:

$$
\% \text { writhing inhibition }=\frac{\mathrm{Wc}-W}{\mathrm{Wc}} \times 100,
$$

where Wc is the mean number of writhes in the control and $W$ is the mean number of writhes in the experimental group (extracts/standard).

2.8. Statistical Data Management and Analysis. The obtained data from anti-inflammatory and analgesic activities were tabulated on MS Excel spreadsheet (2016) and exported to GraphPad Prism statistical software version 8.3.0.538. The data were subjected to descriptive statistics and expressed as mean \pm standard error of the mean (SEM) of replicate experiments. One-Way ANOVA was done to compare differences among means, followed by Tukey's post hoc test for pairwise comparison and separation of means at $\alpha=0.05$. Values with $p \leq 0.05$ were considered statistically significant. Acute oral toxicity data were qualitatively and quantitatively analyzed according to OECD guideline document No. 425 [23], and $\mathrm{LD}_{50}$ values were recorded.

2.9. Ethical Considerations. Permission to conduct this study was obtained from University of Nairobi Ethical Committee and the National Council of Science Technology and Innovation (NACOSTI) under licence number NACOSTI/P/ $19 / 2442$.

\section{Results}

3.1. Acute Oral Toxicity Effects of the Studied Plant Extracts. Acute oral toxicity effects of the aqueous and methanolic stem bark extracts of $P$. thonningii were also investigated in this study. The results demonstrated no observable signs of toxicity and lethal effects in experimental groups of mice even at the limit/cut-off dose of $2000 \mathrm{mg} / \mathrm{kg}$ bw. The $\mathrm{LD}_{50}$ values for each of the studied plant extracts were thus envisaged to be above $2000 \mathrm{mg} / \mathrm{kg}$ bw.

3.2. In Vivo Anti-Inflammatory Effects of the Aqueous and Methanolic Stem Bark Extracts of P. thonningii. The obtained results showed significant reductions in xylene-induced ear oedema in mice. The experimental mice that received $4 \mathrm{mg} /$ $\mathrm{kg}$ bw of the aqueous stem bark extract of $P$. thonningii showed a significantly lower percentage inhibition of xyleneinduced ear oedema in mice, compared with the percentage inhibition produced by the standard drug (dexamethasone) $(p<0.05$; Figure 1).

Generally, a dose-dependent increase in percentage inhibition of xylene-induced ear oedema, caused by this extract was noted among the studied doses. Remarkably, the aqueous stem bark extract of $P$. thonningii at a dose of $500 \mathrm{mg} / \mathrm{kg}$ bw revealed the highest percentage inhibition, compared with the other dose levels of the same extract and the standard drug $(p<0.05$; Figure 1$)$.

Similarly, the results revealed that the methanolic stem bark extract of $P$. thonningii at dose levels of $4 \mathrm{mg} / \mathrm{kg} \mathrm{bw}$, $20 \mathrm{mg} / \mathrm{kg} \mathrm{bw}$, and $100 \mathrm{mg} / \mathrm{kg}$ bw exhibited significantly lower percentage inhibition of xylene-induced ear oedema in experimental mice, compared with the percentage inhibition in mice treated with dexamethasone at a dose of $1 \mathrm{mg} / \mathrm{kg} \mathrm{bw}$ $(p<0.05$; Figure 2).

However, the results showed that the methanolic stem bark extract of the studied plant at a dose of $500 \mathrm{mg} / \mathrm{kg} \mathrm{bw}$ significantly inhibited xylene-induced ear oedema in mice, more than the inhibitions caused by all the other dose levels of the same extract and dexamethasone $(p<0.05$; Figure 2$)$. Overall, a positive dose-dependent increase in percentage inhibition of oedema was observed in the experimental mice that received the studied plant extract (Figure 2).

Moreover, a comparison between the effects of the aqueous and methanolic stem bark extracts of $P$. thonningii in xylene-induced ear oedema was done. The results showed that the experimental mice administered the aqueous stem bark extract of this plant, at all the studied dose levels, showed significantly higher percentage inhibitions of oedema compared with the inhibitions in mice that received the methanolic extract at all the studied dose levels $(p<0.05$; Figure 3).

3.3. In Vivo Analgesic Effects of the Aqueous and Methanolic Stem Bark Extracts of P. thonningii. In this study, the results revealed a dose-dependent reduction in writhing corresponding to an increase in parentage inhibition of acetic acid-induced writhing in mice (Table 1). Upon administration of the aqueous stem bark extract of $P$. thonningii to mice, the percentage inhibition of writhing significantly increased in a dose-dependent manner $(p<0.05$; Table 1$)$.

Notably, at a dose level of $500 \mathrm{mg} / \mathrm{kg} \mathrm{bw}$, the mice that received the aqueous stem bark extract of $P$. thonningii showed significantly reduced writhing, compared to that 


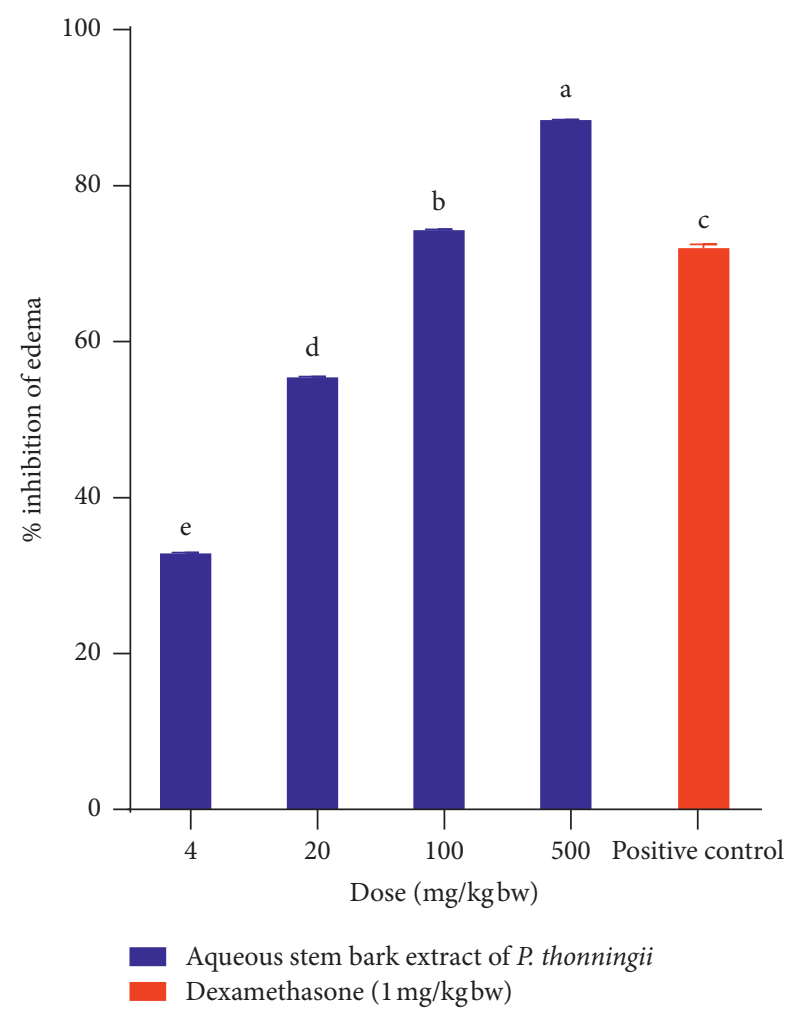

FIgURE 1: Effect of the aqueous stem bark extract of $P$. thonningii on xylene-induced ear oedema in mice. Values are plotted as mean\pm SEM. Bars with different superscript letters are significantly different (One-Way ANOVA followed by Tukey's test; $p<0.05$ ).

recorded for mice in all the other experimental groups including those in the positive control group $(p<0.05$; Table 1).

On the other hand, the mice that received the methanolic stem bark extract demonstrated significantly reduced writhing in a dose-dependent fashion $(p<0.05$; Table 2$)$. The results indicated significantly higher writhing frequency in mice treated with $4 \mathrm{mg} / \mathrm{kg}$ bw compared with the writhes in mice that received the other studied extract doses and the standard drug $(p<0.05$; Table 2$)$.

Conversely, the experimental mice that were administered this extract at a dose level of $500 \mathrm{mg} / \mathrm{kg} \mathrm{bw}$ demonstrated significant lower writhing frequency, compared with the writhing frequencies recorded for mice in all the other experimental groups $(p<0.05$; Figure 2$)$. Interestingly, at a dose level of $500 \mathrm{mg} / \mathrm{kg}$ bw of the methanolic stem bark extract of $P$. thonningii, the recorded number of abdominal writhes was significantly lower than the writhes in the positive control $(p<0.05$; Table 2$)$.

A comparison of the effects of the studied plant extracts on acetic acid-induced writhing in mice was also done in this study (Figure 4). The results revealed that, at all the studied dose levels, the aqueous stem bark extract of $P$. thonningii conferred significantly higher percentage inhibition (less writhing frequency) of acetic acid-induced writhing compared to its methanolic counterpart at the same dose levels $(p<0.05$; Figure 4$)$.

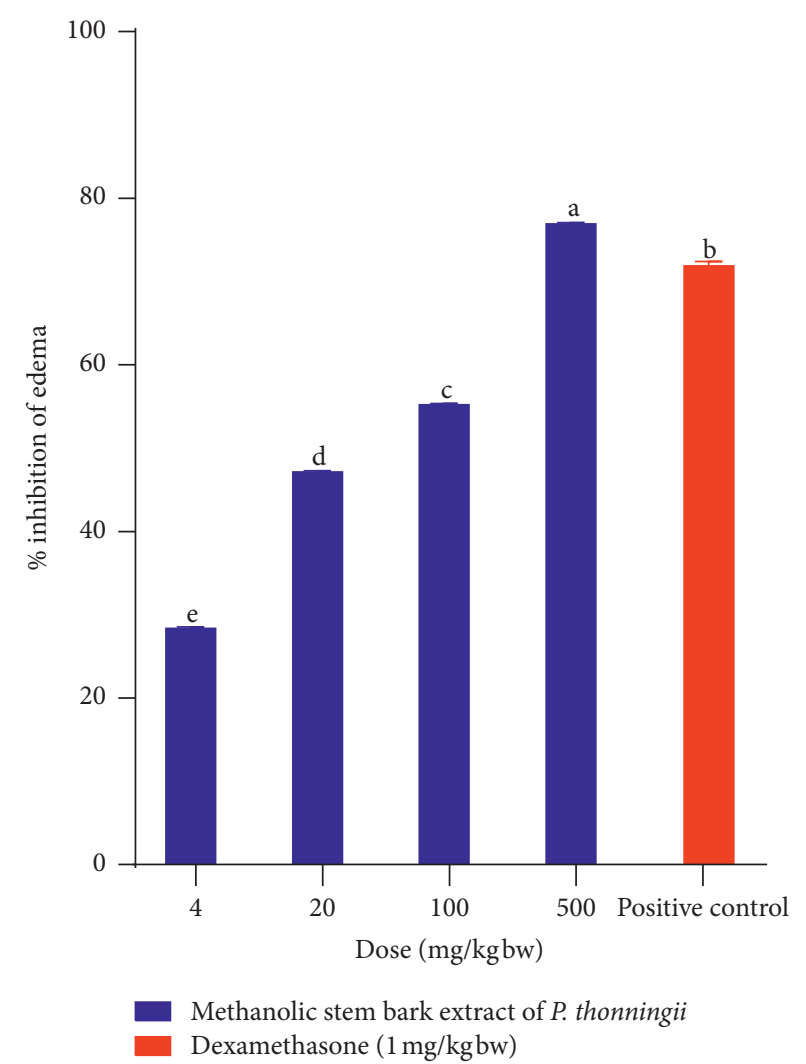

FIGURE 2: Effect of the methanolic stem bark extract of $P$. thonningii on xylene-induced ear oedema in mice. Values are plotted as mean \pm SEM. Bars with different superscript letters are significantly different (One-Way ANOVA followed by Tukey's test; $p<0.05$ ).

\section{Discussion}

Inflammation is the wellspring of symptoms elicited by maladies affecting the body. It is a multifaceted biological response by vascular tissues to injurious stimuli like pathogens, damaged cells, physical and chemical assaults, as well as immunological responses [25]. As far as humankind and health are concerned, understanding of inflammation and associated processes has been a major conundrum [26].

The cardinal signs which characterize inflammation include increased cellular metabolism, release of cellular soluble inflammatory mediators, increased blood flow, vasodilation, extravasation of fluids and cellular influx, formation of abnormal granulations, necrosis, and excessive tissue degeneration and exudation. All these lead to varying degrees of tissue injuries and can even lead to death [1].

In this study, acute inflammation was evaluated using the xylene-induced ear oedema technique. Xylene is a chemical inflammatory trigger which causes release of inflammatory mediators including histamine, bradykinin, and serotonin [27]. Consequently, there is greater permeability in the vasculature with elevated vasodilation. The result is the accumulation of fluid at the inflamed/induced site observed in the xylene-induced ear oedema in mice [27].

A drug agent that is capable of inhibiting fluid accumulation in this technique is considered as having anti- 


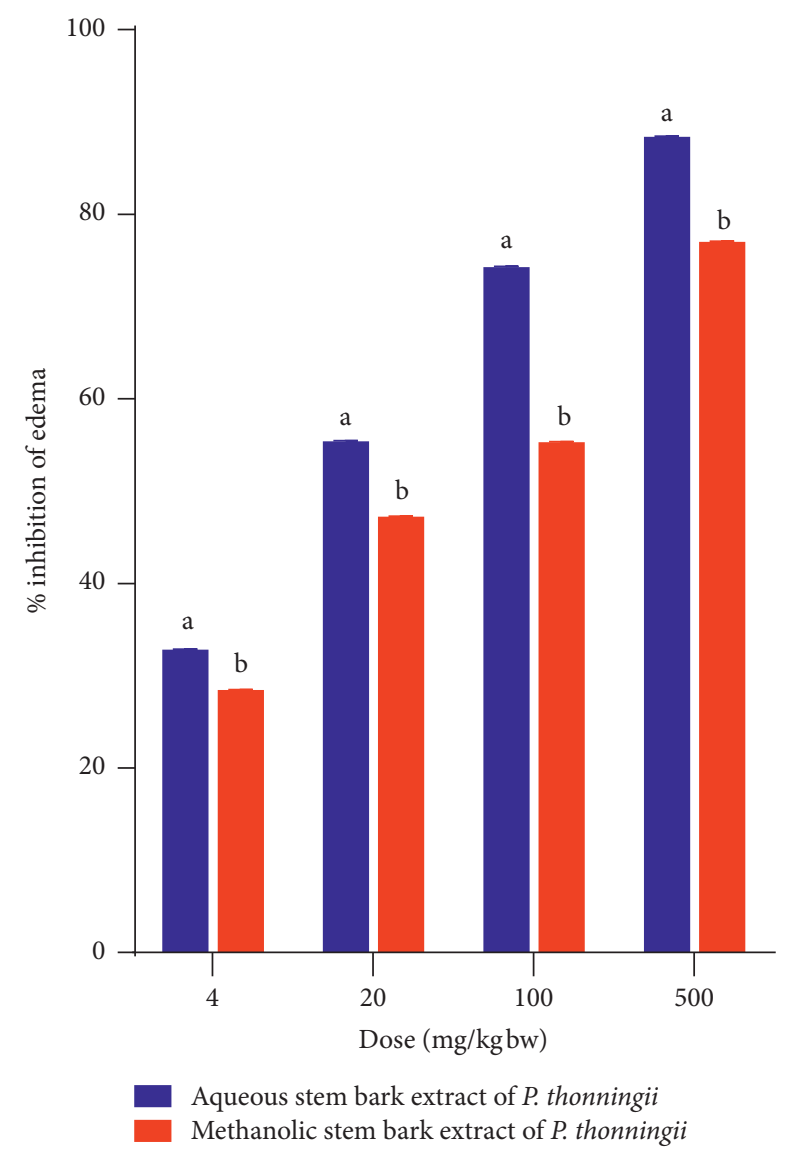

Figure 3: Comparison between the effects of the studied plant extracts on xylene-induced ear oedema. Values are plotted as mean \pm SEM. Bars with different superscript letters within the same dose level are significantly different (Un-paired Student's $t$-test; $p<0.05)$.

TABLE 1: Effects of the aqueous stem bark extract of $P$. thonningii on acetic acid-induced writhing in mice.

\begin{tabular}{lcc}
\hline & $\begin{array}{c}\text { Aqueous stem bark extract of } \\
\text { Dose }(\mathrm{mg} / \mathrm{kg} \mathrm{bw})\end{array}$ & $\begin{array}{c}\text { P. thonningii } \\
\text { Writhing }\end{array}$ \\
& frequency & inhibition \\
\hline 4 & $66.20 \pm 1.16^{\mathrm{b}}$ & 29.72 \\
20 & $56.40 \pm 2.04^{\mathrm{c}}$ & 40.13 \\
100 & $24.80 \pm 1.86^{\mathrm{d}}$ & 73.67 \\
500 & $14.00 \pm 1.14^{\mathrm{e}}$ & 85.14 \\
Acetylsalicylic acid $(75 \mathrm{mg} /$ & $15.40 \pm 1.21^{\mathrm{e}}$ & 83.65 \\
kg bw) & $94.20 \pm 3.97^{\mathrm{a}}$ & 0 \\
Negative control &
\end{tabular}

Values are presented as mean \pm SEM; means with different superscript letters along the column are significantly different (One-Way ANOVA followed by Tukey's test; $p<0.05$ ).

inflammatory activity [27]. The results reported herein suggest remarkable anti-inflammatory effects of the aqueous and methanolic stem bark extracts of $P$. thonningii as evidenced by their ability to inhibit/reduce xylene-induced ear oedema in experimental mice. Particularly, the aqueous stem bark extract
TABle 2: Effect of the methanolic stem bark extract of $P$. thonningii on acetic acid-induced writhing in mice.

\begin{tabular}{lcc}
\hline Dose $(\mathrm{mg} / \mathrm{kg} \mathrm{bw})$ & $\begin{array}{c}\text { Methanolic stem bark extract of } P . \\
\text { thonningii }\end{array}$ \\
& Writhing frequency & \% inhibition \\
\hline 4 & $83.80 \pm 3.14^{\mathrm{b}}$ & 11.04 \\
20 & $68.60 \pm 1.44^{\mathrm{c}}$ & 27.18 \\
100 & $40.00 \pm 1.41^{\mathrm{d}}$ & 57.54 \\
500 & $25.40 \pm 1.12^{\mathrm{e}}$ & 73.04 \\
Acetylsalicylic acid & $15.40 \pm 1.21^{\mathrm{f}}$ & 83.65 \\
(75 mg/kg bw) & $94.20 \pm 3.97^{\mathrm{a}}$ & 0 \\
\hline Negative control &
\end{tabular}

Values are presented as mean \pm SEM; means with different superscript letters along the column are significantly different (One-Way ANOVA followed by Tukey's test; $p<0.05$ ).



Figure 4: Comparison between the effects of the studied plant extracts on acetic acid-induced writhing in mice. Values are plotted as mean \pm SEM. Bars with different superscript letters within the same dose level are significantly different (Un-paired Student's t-test; $p>0.05$ ).

of $P$. thonningii proved to be more potent than the methanolic extract of the same plant, at all the studied dose levels.

The current medications used to avert inflammation are topical steroids and nonsteroidal anti-inflammatory drugs which work by inhibiting the activity of phospholipase $\mathrm{A}_{2}$ $[5,28,29]$. It is suggestive that partly the studied plant extracts could be working through this mechanism. 
Moreover, research has established that peripheral action differs from central action, and some centrally acting drugs, such as opioids, inhibit both phases of nociception equally [30]. Even though the specific mechanism through which the studied plant extracts exert their bioactivity has not been debunked, it is suggestive that the compounds in these extracts could possess both peripheral and central analgesic/ anti-inflammatory effects.

Generally, acetic acid-induced writhing test serves as a standard technique for evaluating antinociceptive/analgesic efficacy of natural products $[31,32]$. In this method, acetic acid induces the release of various endogenous noxious mediators such as histamine, serotonin, and bradykinin which drive the cardinal signs associated with inflammation, especially pain [27]. The pain brought by the acetic acid is evidenced in the contraction of abdominal muscles and the expansion of forelimbs, as well as body elongation, that is generally regarded as writhing, whose frequency is quantified in 30 minutes $[7,27]$. This elongation is thought to be caused by the activation of local peritoneal receptors and prostaglandin pathways in the experimental model animal, by appropriate chemicals like acetic acid [33].

Upon injection of acetic acid intraperitoneally into experimental mice, it causes the release of inflammatory mediators which excites pain receptors (nociceptors), which in turn send pain messages to the central nervous system and the brain through the prostaglandin system [34]. Furthermore, other pain mediators like bradykinins and histamine are released from cells lining the peritoneal cavity and further help stimulate nociceptors [9, 35]. Agents which reduce/inhibit the acetic acid-induced writhing frequency are considered as having analgesic effects.

In this study, the studied stem bark extracts of $P$. thonningii plant showed significant inhibition of the acetic acid-induced writhing in a manner that suggests blockade/ inhibition of the prostaglandin pathway in the pain perception cascade. Previous studies have shown that drugs which inhibit the cyclooxygenase enzyme pathway inhibit writhing, which is an indicator of pain in experimental animal models [36].

The findings of this study agree with those reported in a previous study; that is, NSAIDs reduce the number of writhes by inhibiting cyclooxygenase in peripheral tissues [36]. The aqueous and methanolic stem bark extracts of the studied plant may be acting through a similar mechanism in averting pain in this study. Indeed, the findings of this study are consistent with previous studies which indicated that the aqueous leaf extract of $P$. thonningii possess demonstrable analgesic activity in the writhing test [21].

Further, anti-inflammatory compounds have been isolated from the leaf extracts of $P$. thonningii growing in Nigeria [18]. Among the isolated compounds, 6-C-methylquercetin $3,7,3^{\prime}$-trimethyl ether (3) proved to be a potent prostaglandin synthesis inhibitor, indicating a promising potential of this plant as a source of potent anti-inflammatory agents [18].

It has been demonstrated that oxidative stress plays a role in inflammatory processes, and that antioxidant compounds play major roles in amelioration of inflammation [37].
Preliminary phytochemical investigations of aqueous and methanolic stem bark extracts of $P$. thonningii have shown presence of flavonoids and phenols among other antioxidant phytocompounds [41]. Further, an earlier study by Kwaji et al. [42] on the aqueous leaf extract of $P$. thonningii showed presence of antioxidant phytochemicals which are associated with anti-inflammatory activity [41]. It is therefore anticipated that the analgesic and anti-inflammatory effects of the studied extracts could be due to these secondary metabolites.

Although most of drugs presently used to manage pain and inflammation are effective, they have been associated with toxic effects and adverse side effects as noted by Deghrigue et al. [40]. As a result, there is a continuous search for alternative treatments that can alleviate these conditions with minimum adverse events. Herbal medicines have been established to be a safe alternative due to their natural origin, cultural adaptability, availability, and safety [42].

Despite the utilization of herbal preparations in traditional medicine for a long time by humans to manage a variety of diseases, their safety and toxicity have raised concerns [43]. This has been exacerbated by the lack of clear guidelines and policies on traditional medicine practice, dosage regimes, formulations of herbal preparations, and little understanding of modes of action and drug interactions as well as toxicity profiles $[44,45]$. As a result, it is imperative to investigate the safety of medicinal plants used in traditional medicine to provide essential scientific data, which can guide the validation of their claimed healing efficacies [46, 47].

In this study, acute oral toxicity effects of both the methanolic and aqueous stem bark extracts of $P$. thonningii were investigated according to the guidelines described by the OECD [23]. There were no observable signs of toxicity in the experimental group mice at the various dose levels, up to the cut-off dose of $2000 \mathrm{mg} / \mathrm{kg} \mathrm{bw}$. Thus, the study agrees with previous findings, such as those by $[48,49]$ which had found acute toxicity to be very low and that the extract is practically nontoxic at oral doses. Furthermore, [50] reported that the leaf fraction of $P$. thonningii was not toxic to rats at oral doses.

These results indicate that the aqueous and methanolic stem bark extracts of this plant are nontoxic to laboratory rodents. Studies have shown that the presence of toxic secondary metabolites is responsible for the adverse side effects reported when some plants or their products have been consumed [51]. Indeed, based on the results herein, the studied plant extracts, either lack the toxic amalgams, or are present in too low levels to cause any observable signs of toxicity. Therefore, these results partly support the traditional use of the studied plant extracts in the management of pain, and inflammation, among other claimed conditions $[14,16,42,52]$. However, further studies are imperative to fully establish their safety and dosage formulations, as well as to understand drug interaction effects.

\section{Conclusions and Recommendations}

Based on the results obtained in this study, it was concluded that the aqueous and methanolic stem bark extracts of $P$. thonningii have acute anti-inflammatory and analgesic effects in Swiss albino mice. Furthermore, the aqueous and 
methanolic stem bark extracts of $P$. thonningii have $\mathrm{LD}_{50}$ values of $>2000 \mathrm{mg} / \mathrm{kg}$ bw and are thus nontoxic as per the guidelines of OECD [23]. Therefore, the aqueous and methanolic stem bark extracts of $P$. thonningii can be utilized as alternatives in the management of inflammation and pain, as claimed in traditional medicine.

Nevertheless, there is a need to bio-screen the studied extracts of $P$. thonningii to identify and isolate the specific compounds with analgesic and anti-inflammatory activities. This way, new compounds might be discovered, which will be used for treatment of the two conditions: pain and inflammation. Additionally, future studies should focus on elucidation of the possible mechanism(s) for analgesic and anti-inflammatory actions of the aqueous and methanolic stem bark extracts studied herein. In addition to acute toxicity, there is a need to evaluate chronic toxicity to determine the safety of the bark extracts in animal models.

\section{Data Availability}

All data are available within the manuscript, and additional data are available from the corresponding authors on request.

\section{Conflicts of Interest}

The authors declare that no conflicts of interest exist regarding this publication.

\section{Authors' Contributions}

Ben Olela, James Mbaria, and Timothy Wachira conceived the research idea. Ben Olela performed the experiments and drafted the manuscript. Gervason Moriasi designed and guided the experiments and assisted with data analysis and interpretation. James Mbaria and Timothy Wachira supervised the entire study. All authors reviewed and approved the final manuscript for publication.

\section{Acknowledgments}

The authors would like to acknowledge the Department of Public Health, Pharmacology and Toxicology of the University of Nairobi for providing the lab facility, model animals, reagents, and equipment for this study. Mr. Maloba of the Department of Public Health, Pharmacology and Toxicology (UoN) and Mr. Nelson of Department of Biological Sciences (MKU) are appreciated for their technical assistance.

\section{References}

[1] J. Oschman, G. Chevalier, and R. Brown, "The effects of grounding (earthing) on inflammation, the immune response, wound healing, and prevention and treatment of chronic inflammatory and autoimmune diseases," Journal of Inflammation Research, vol. 8, pp. 83-96, 2015.

[2] K. Gou, R. Zeng, Y. Dong, Q. Hu, and H. Hu, "Anti-inflammatory and analgesic effects of Polygonum orientale L. extracts," Frontiers in Pharmacology, vol. 8, 2017.
[3] O. O. Oguntibeju, "Medicinal plants with anti-inflammatory activities from selected countries and regions of Africa," Journal of Inflammation Research, vol. 11, pp. 307-317, 2018.

[4] A. Alemu, W. Tamiru, T. Nedi, and W. Shibeshi, "Analgesic and anti-inflammatory effects of $80 \%$ methanol extract of leonotis ocymifolia (Burm. f.) iwarsson leaves in rodent models," Evidence-Based Complementary and Alternative Medicine, vol. 2018, Article ID 1614793, 8 pages, 2018.

[5] K. Lalrinzuali, M. Vabeiryureilai, and G. C. Jagetia, "Investigation of the anti-inflammatory and analgesic activities of ethanol extract of stem bark of sonapatha oroxylum indicum in vivo," International Journal of Inflammation, vol. 2016, Article ID 8247014, 8 pages, 2016.

[6] M. Ghasemian, S. Owlia, and M. B. Owlia, "Review of antiinflammatory herbal medicines," Advances in Pharmacological Sciences, vol. 2016, Article ID 9130979, 11 pages, 2016.

[7] A. Azab, A. Nassar, and A. N. Azab, "Anti-inflammatory activity of natural products,” Molecules, vol. 21, no. 10, p. 1321, 2016.

[8] A. Chatterjee, B. Sen, S. Das, and T. Chatterjee, "Anti-inflammatory and alalgesic activity of methanoic extract of medicinal plant Rhodiola rosea I. Rhizomes," International Journal of Pharma Research \& Review, vol. 4, no. 2, pp. 1-8, 2015.

[9] R. Borges, M. V. M. Nascimento, A. A. V. De Carvalho et al., "Antinociceptive and anti-inflammatory activities of the ethanolic extract from synadenium umbellatum pax. (Euphorbiaceae) leaves and its fractions," Evidence-Based Complementary and Alternative Medicine, vol. 2013, Article ID 715650, 9 pages, 2013.

[10] S. Omoigui, "The biochemical origin of pain-proposing a new law of pain: the origin of all pain is inflammation and the inflammatory response. Part 1 of 3-a unifying law of pain," Medical Hypotheses, vol. 69, no. 1, pp. 70-82, 2007.

[11] K. Donkor, S. Antwi, J. Asiedu-Larbi, N. Takyi, N. Martey, and L. Okine, "Analgesic and anti-inflammatory activities of Asena, a herbal preparation for treatment of arthritis, using rodent models," Medicinal and Aromatic Plant Research Journal, vol. 1, no. 2, pp. 20-29, 2013.

[12] R. Fürst and I. Zündorf, "Plant-derived anti-inflammatory Compounds: hopes and disappointments regarding the translation of preclinical knowledge into clinical progress," Mediators of Inflammation, vol. 2014, Article ID 146832, 9 pages, 2014.

[13] Piliostigma thonningii (PROTA)-plantuse english. (n.d.)., ," 2020, https://uses.plantnet-project.org/en/Piliostigma thonningii_(PROTA).

[14] P. G. Kareru, G. M. Kenji, A. N. Gachanja, J. M. Keriko, and G. Mungai, "Traditional medicines among the Embu and Mbeere peoples of Kenya," African Journal of Traditional, Complementary and Alternative Medicines, vol. 4, no. 1, pp. 75-86, 2007.

[15] R. I. Ozolua, P. Alonge, and I. Igbe, "Effects of leaf extracts of piliostigma thonningii schum on aortic ring contractility and bleeding time in rats," Journal of Herbs, Spices and Medicinal Plants, vol. 15, no. 4, pp. 326-333, 2009.

[16] S. N. Wambugu, P. M. Mathiu, D. W. Gakuya, T. I. Kanui, J. D. Kabasa, and S. G. Kiama, "Medicinal plants used in the management of chronic joint pains in Machakos and Makueni counties, Kenya," Journal of Ethnopharmacology, vol. 137, no. 2, pp. 945-955, 2011.

[17] M. Afolayan, R. Srivedavyasasri, O. T. Asekun et al., "Phytochemical study of Piliostigma thonningii, a medicinal plant grown in Nigeria," Medicinal Chemistry Research, vol. 27, no. 10, pp. 2325-2330, 2018. 
[18] J. C. Ibewuike, F. O. Ogungbamila, A. O. Ogundaini, I. N. Okeke, and L. Bohlin, "Antiinflammatory and antibacterial activities of C-methylflavonols from Piliostigma thonningii," Phytotherapy Research, vol. 11, no. 4, pp. 281-284, 1997.

[19] I. Igbe, C. Eboka, P. Alonge, and Q. Osazuwa, "Analgesic and anti-inflammatory activity of the aqueous leaf extract of Piliostigma thonningii (Caesalpinoideae)," Journal of Pharmacy \& Bioresources, vol. 9, no. 1, pp. 34-38, 2013.

[20] J. B. Harborne, Phytochemical Methods: a Guide to Modern Techniques of plant Analysis, Cox \& Wyman Ltd., Fakenham, Norfolk, 1976.

[21] Y. Bibi, S. Nisa, M. Zia, A. Waheed, S. Ahmed, and M. Chaudhary, "In vitro cytotoxic activity of Aesculus indica against breast adenocarcinoma cell line (MCF-7) and phytochemical analysis," Pakistan Journal of Pharmaceutical Sciences, vol. 25, no. 1, pp. 183-187, 2012.

[22] Erhierhie, E. Oghenesuvwe, N. E. Ekene, and A. Daniel Lotanna, "Guidelines on dosage calculation and stock solution preparation in experimental animals' studies," Journal of Natural Sciences Research Www, vol. 4, no. 18, pp. 2225-2921, 2014.

[23] Organisation for Economic Cooperation and Development (OECD), "Test no. 425: acute oral toxicity: up-and-down procedure," OECD Guidelines for the Testing of Chemicals, Section 4, 2008.

[24] M. H. Rashid, B. Sujit, A. Mohammed, and R. B. Jamilur, "Phytochemical screening and analgesic, anti-bacterial and cytotoxic activity evaluation of ethanol extract of Pithcellobiumdulce (roxb.) Benth leaf," Asian Journal of Pharmaceutical and Clinical Research, vol. 8, no. 2, pp. 451-457, 2015.

[25] S. M. M. Rahman, N. Islam, and F. Ahammad, "Anti-inflammatory, antinociceptive and antidiarrhoeal activities of methanol and ethyl acetate extract of Hemigraphis alternata leaves in mice," Clinical Phytoscience, vol. 5, no. 1, 2019.

[26] M. J. Wanja, "Evaluation of the antinociceptive, antipyretic, and anti-inflammatory properties of methanolic park extracts of Terminalia brownii in Wister Rats," Masters thesis, Kenyatta University, Nairobi, Kenya, 2016.

[27] N. Yasmen, A. Aziz, A. Tajmim, M. I. Akter, A. K. Hazra, and S. M. M. Rahman, "Analgesic and anti-inflammatory activities of diethyl ether and $N$-hexane extract of Polyalthia suberosa leaves," Evidence-Based Complementary and Alternative Medicine, vol. 2018, Article ID 5617234, 8 pages, 2018.

[28] O. Ovuakporie-uvo, M. Idu, P. Obarisiagbon, and C. Abode, "Analgesic, pro and anti-inflammatory activities of Desplatsia dewevrei; cytokine gene expression using wistar rats and mice," The Journal of Phytopharmacology, vol. 7, no. 2, pp. 185-190, 2018.

[29] K. Sun, X. Song, R. Jia et al., "Evaluation of analgesic and antiinflammatory activities of water extract of galla chinensis in vivo models," Evidence-Based Complementary and Alternative Medicine, vol. 2018, Article ID 6784032, 7 pages, 2018.

[30] D. Kaushik, A. Kumar, P. Kaushik, and A. C. Rana, "Analgesic and anti-inflammatory activity of pinus roxburghii sarg," Advances in Pharmacological Sciences, vol. 2012, Article ID 245431, 6 pages, 2012.

[31] M. Mueller, S. Hobiger, and A. Jungbauer, "Anti-inflammatory activity of extracts from fruits, herbs and spices," Food Chemistry, vol. 122, no. 4, pp. 987-996, 2010.

[32] J. Zhen, Y. Guo, T. Villani et al., "Phytochemical analysis and anti-inflammatory activity of the extracts of the african medicinal plant Ximenia caffra," Journal of Analytical Methods in Chemistry, vol. 2015, no. 9, Article ID 948262, 2015.

[33] S. Gawade, "Acetic acid induced painful endogenous infliction in writhing test on mice," Journal of Pharmacology and Pharmacotherapeutics, vol. 3, no. 4, p. 348, 2012.

[34] A. Bhattacharya, S. Kumar, S. Mishra, S. Patnaik, P. Sahu, and D. Agrawal, "Analgesic effect of ethanolic leaf extract of Moringa oleifera on albino mice," Indian Journal of Pain, vol. 28, no. 2, pp. 89-94, 2014.

[35] F. R. Nonato, T. A. A. Barros, A. M. Lucchese et al., "Antiinflammatory and antinociceptive activities of Blechnum occidentale L. extract," Journal of Ethnopharmacology, vol. 125, no. 1, pp. 102-107, 2009.

[36] A. Shojaii, M. Motaghinejad, S. Norouzi, and M. Motevalian, "Evaluation of anti-inflammatory and analgesic activity of the extract and fractions of Astragalus hamosus in animal models," Iranian Journal of Pharmaceutical Research: IJPR, vol. 14, no. 1, pp. 263-269, 2015.

[37] P. Arulselvan, M. T. Fard, W. S. Tan et al., "Role of antioxidants and natural products in inflammation," Oxidative Medicine and Cellular Longevity, vol. 2016, no. 15, Article ID 5276130, 2016.

[38] G. A. Moriasi, A. M. Ireri, and M. P. Ngugi, "In vivo cognitiveenhancing, ex vivo malondialdehyde-lowering activities and phytochemical profiles of aqueous and methanolic stem bark extracts of Piliostigma thonningii (schum.)," International Journal of Alzheimer's Disease, vol. 2020, Article ID 1367075, 15 pages, 2020.

[39] A. Kwaji, P. Usman Bassi, and O. George Ademowo, "Preliminary studies on Piliostigma thonningii Schum leaf extract: phytochemical screening and in vitro antimalarial activity," African Journal of Microbiology Research, vol. 4, no. 9, pp. 735-739, 2010.

[40] M. Deghrigue, S. Lajili, M. Turki, N. Eltaief, and A. Bouraout, "Evaluation of anti-inflammatory, analgesic and gastroprotective activities of Eunicella singularis fractions using in vivo assays," Annals Medical and Biomedical Sciences, vol. 1, no. 6, pp. 23-28, 2015.

[41] A. G. Kurmukov, "Phytochemistry of medicinal plants," Medicinal Plants of Central Asia: Uzbekistan and Kyrgyzstan, vol. 1, no. 6, pp. 13-14, 2013.

[42] WHO, WHO Herbal Sale Rates, vol. 26, WHO, Geneva, Switzerland, 2013http://apps.who.int/iris/bitstream/10665/ 92455/1/9789241506090_eng.pdf?ua=1.

[43] P. George, "Concerns regarding the safety and toxicity of medicinal plantsan overview," Journal of Applied Pharmaceutical Science, vol. 1, no. 6, pp. 40-44, 2011.

[44] H. Nasri and H. Shirzad, "Toxicity and safety of medicinal plants," Journal of HerbMed Pharmacology, vol. 2, no. 2, pp. 21-22, 2013.

[45] B. Saad, H. Azaizeh, G. Abu-Hijleh, and O. Said, "Safety of traditional Arab herbal medicine," Evidence-Based Complementary and Alternative Medicine, vol. 3, no. 4, pp. 433-439, 2006.

[46] A. Aydin, G. Aktay, and E. Yesilada, "A guidance manual for the toxicity assessment of traditional herbal medicines," Natural Product Communications, vol. 11, no. 11, pp. 17631773, 2016.

[47] S. Chanda, J. Parekh, Y. Vaghasiya, R. Dave, Y. Baravalia, and R. Nair, "Medicinal plants -from traditional use to toxicity assessment: a Review," International Journal of Pharmaceutical Sciences and Research IJPSR, vol. 6, no. 7, pp. 2652-2670, 2015. 
[48] J. Adjene and P. Igbigbi, "Histological effects of long-term administration of Piliostigma thonningii stem bark on the liver of adult Wistar rats," Anatomy Journal of Africa, vol. 2, no. 2, 2013.

[49] S. Daniyan, M. Galadima, U. Ijah, and L. Odama, "Short term acute and subacute toxicity studies on $P$. thonningii leaf extract in rats," International Journal of Researchin Ayurvella and Pharmacy, vol. 2, no. 2, pp. 481-483, 2011.

[50] A. Ukwuani, O. Ihebunna, S. Rm, and P. Ij, "Acute oral toxicity and antiulcer activity of Piliostigma thonningii leaf fraction in albino rats," Bulletin of Environment, Pharmacology and Life Sciences, vol. 2, no. 1, pp. 41-45, 2012.

[51] R. J. Molyneux, S. T. Lee, D. R. Gardner, K. E. Panter, and L. F. James, "Phytochemicals: the good, the bad and the ugly?" Phytochemistry, vol. 68, no. 22-24, pp. 2973-2985, 2007.

[52] J. O. Igoli, I. C. Igwue, and N. P. Igoli, "Traditional medicinal practices among the igede people of Nigeria," Journal of Herbs, Spices \& Medicinal Plants, vol. 10, no. 4, pp. 1-10, 2004.

[53] Orwa, "Piliostigma thonningii Piliostigma thonningii ( schum.) milne-redh," Aggroforestry Database, vol. 4, pp. 1-5, 2009. 